\title{
Hepatitis C infection in Egypt: prevalence, impact and management strategies [Corrigendum]
}

Asmaa Gomaa, Naglaa Allam, Aisha Elsharkway, Mohamed El Kassas, Imam Waked Hepat Med. 2017;9:17-25.

There is a spelling error for one of the authors, Aisha Elsharkway should be Aisha Elsharkawy.

\section{Publish your work in this journal}

Hepatic Medicine: Evidence and Research is an international, peerreviewed, open access journal covering all aspects of adult and pediatric hepatology in the clinic and laboratory including the following topics: Pathology, pathophysiology of hepatic disease; Investigation and treatment of hepatic disease; Pharmacology of drugs used for the treatment of hepatic disease. Issues of patient safety and quality of care will also be considered. The manuscript management system is completely online and includes a very quick and fair peer-review system, which is all easy to use. Visit http://www.dovepress.com/testimonials.php to read real quotes from published authors.

Submit your manuscript here: https://www.dovepress.com/hepatic-medicine-evidence-and-research-journal 